\title{
Desain Antena Hexagonal Patch Array Berbasis Sistem Transfer Daya Wireless pada Frekuensi $2,4 \mathrm{GHz}$
}

\section{Hexagonal Patch Array Antenna Design Based on Wireless Power Transfer at Frequency of $2.4 \mathrm{GHz}$}

\author{
Herma Nugroho R. A. K. , Sholeh Hadi P., dan Erni Yudaningtyas \\ Program Studi Magister Teknik Elektro, Universitas Brawijaya Malang \\ Jalan M.T. Haryono No. 167, Malang 65145, Indonesia
}

\begin{abstract}
Abstrak
Pada penelitian ini telah didesain antena hexagonal patch array yang dapat digunakan sebagai perangkat catu daya wireless. Antena hexagonal patch array ini didesain untuk menangkap gelombang radio (RF) pada frekuensi 2,4 GHz yang dapat diaplikasikan sebagai antena pada Wireless Local Area Network (WLAN). Desain antena dilakukan menggunakan software CST Microwave studio, kemudian dilakukan pabrikasi dan pengukuran secara riil. Parameter pengujian antena hexagonal patch array meliputi return loss, Voltage Standing Wave Ratio (VSWR), gain, bandwidth, dan daya. Metode yang digunakan adalah pemodelan transmission line dan corporate feed line untuk pengaturan perubahan jarak antar patch antena. Perubahan variabel juga diteliti pengaruhnya terhadap parameter antena khususnya daya terima antena yang kemudian ditransmisikan ke rangkaian power harvester. Nilai parameter antena hasil simulasi menunjukkan nilai return loss adalah -33,38 $\mathrm{dB}$, VSWR sebesar 1,041, gain sebesar 8,81 dBi, bandwidth adalah $0,084 \mathrm{GHz}$, daya sebesar 0,499 W (-3 dBm). Sedangkan parameter hasil pengukuran dari antena yang telah dipabrikasi adalah nilai return loss sebesar -33,21 dB, VSWR sebesar 1,048, gain sebesar $5 \mathrm{dBi}$, bandwidth adalah $0,145 \mathrm{GHz}$, daya sebesar $-33 \mathrm{dBm}$.
\end{abstract}

Kata kunci: patch, array, wireless, rectifier, return loss.

\section{Abstract}

In this research, the hexagonal patches antenna array as a wireless power source device has been designed. This antenna is designed to receive the RF energy at frequency of $2.4 \mathrm{GHz}$ for WLAN application. CST Microwave studio and multisim software tools are used for simulation purposes and then the real fabrication and measurement are carried out. Testing of the antenna parameters consists of return loss, Voltage Standing Wave Ratio (VSWR), gain, bandwidth, and power. The method of research is transmission line modelling and corporate feed line for setting of change distance between patches an antenna. The simulated results show that return loss is $-33.38 \mathrm{~dB}$, VSWR is 1.041, gain is $8.81 \mathrm{dBi}$, bandwidth is $0.084 \mathrm{GHz}$ and the power is $0.499 \mathrm{~W}(-3$ $\mathrm{dBm}$ ). Whereas the measurement results show that return loss is $-33.21 \mathrm{~dB}$, VSWR is 1.048, gain is $5 \mathrm{dBi}$, bandwidth is 0.145 $\mathrm{GHz}$ and the power is $-33 \mathrm{dBm}$.

Keywords: patch, array, wireless, rectifier, return loss.

\section{Pendahuluan}

Wireless power transfer (WPT) merupakan transmisi energi secara wireless dari sumber listrik ke beban listrik. Penggunaan transmisi ini dilakukan jika koneksi kabel tidak memungkinkan menjangkau beban. Salah satu teknologi WPT yang dapat digunakan untuk mengatasi permasalahan jangkauan kabel atau jarak sumber yang sangat jauh dari beban adalah rectenna [1].

Rectenna adalah kombinasi dari dua kata yaitu rectifier dan antenna. Rectifier akan mengkonversi energi Radio Frequency (RF) menjadi tegangan Direct Current (DC) sedangkan antenna sebagai penerima energi RF. Output tegangan dari rectenna dapat digunakan untuk menjalankan beban listrik misalnya sensor, kapal tanpa awak, light emitting diode (LED) dan sebagainya [2].

\footnotetext{
* Corresponding Author

Email: hnugroho81@gmail.com

Received: November 19, 2015; Revised: November 26, 2015

Accepted: December 19, 2015

Published: December 30, 2015

(c) 2015 PPET - LIPI

doi : $10.14203 /$ jet.v15.33-38
}

Ada beberapa faktor yang mempengaruhi output rectenna antara lain adalah topologi antena, rangkaian rectifier dan kombinasi dari keduanya. Topologi dan susunan antena, misalnya disusun array diharapkan mampu menangkap sinyal RF secara maksimal sehingga akan dapat memperbaiki RF power harvesting [3]. Faktor berikutnya yaitu tentang susunan rectifier misalnya digunakan voltage double rectifier sehingga tegangan output meningkat [2]. Selanjutnya, faktor kombinasi dari susunan antena dan rectifier yang diharapkan menghasilkan output daya yang besar [3].

Peningkatan daya pada suatu antena tentunya akan berpengaruh terhadap nilai output rectifier. Berdasarkan penelitian sebelumnya dengan nilai tegangan rectifier masih kecil $(0,818 \mathrm{~V}$ dan $0,73 \mathrm{~V})$ [2], [4] maka diperlukan suatu metode desain untuk peningkatan daya antena.

Secara garis besar metode desain yang digunakan pada antena mikrostrip array adalah metode corporate feed line dan series feed line. Berdasarkan penelitian sebelumnya bahwa metode series feed line memiliki beberapa kelemahan antara lain nilai gain dan return loss yang rendah. Sedangkan pada corporate feed line 
memiliki beberapa kelebihan antera lain mudah dalam implementasi, adanya kontrol daya pada saluran tiap elemen, gain dan return loss yang besar [5]. Fokus pada penelitian ini adalah desain antena sebagai catu daya menggunakan metode corporate feed line dengan kombinasi susunan antena array berbentuk hexagonal.

\section{LANDASAN TEORI}

Transfer daya wireless merupakan salah satu teknik pengambilan energi langsung dari alam bebas menggunakan elektromagnetik sebagai sumber energinya. Teknik ini akan optimal apabila ditunjang dengan metode yang tepat. Dalam hal ini, metode desain yang digunakan yaitu corporate feed line

\section{A. Rectenna}

Rectenna pada dasarnya merupakan sebuah perangkat yang mengkonversi energi RF menjadi sebuah tegangan DC. Ini adalah kombinasi dari dua kata yaitu rectifier dan antenna. Rectifier akan mengkonversi energi RF menjadi tegangan DC sedangkan antenna sebagai penerima energi RF [1].

Rectenna memiliki potensi besar untuk mengirim, mengumpulkan, dan mengkonversi energi frekuensi radio dalam daya DC yang berguna untuk me-recharge perangkat elektronik berdaya rendah melalui ruang bebas tanpa menggunakan jalur transmisi fisik. Adapun blok diagram dari sistem rectenna ditunjukkan dalam Gambar 1. Energi RF akan diterima oleh antena yang selanjutnya akan diubah menjadi energi listrik berupa sinyal Alternating Current/ sinyal bolak-balik (AC). Daya dari antena akan mengalami transfer daya maksimum ke beban di rectifier apabila impedansi antena sama dengan impedansi beban, sehingga diperlukan rangkaian penyeseuai impedansi (matching network). Pada rangkaian rectifier sinyal AC tersebut dikonversi menjadi sinyal DC, kemudian sinyal ini akan menjalankan beban.

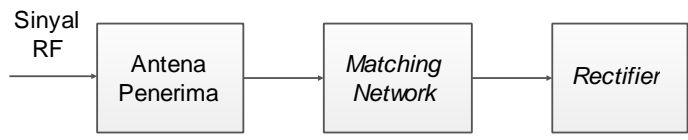

Gambar 1. Blok Diagram Sistem Rectenna [6].

\section{B. Metode Corporate Feed Line}

Penggambaran tentang metode ini dapat dijelaskan pada feed antena array linear dengan 2 patch antena sesuai Gambar 2.

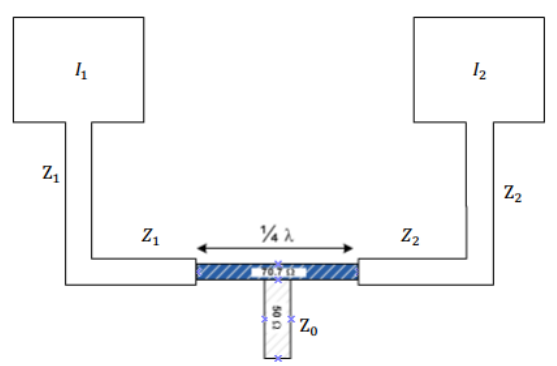

Gambar 2. Dua Patch Linear Array Dengan Corporate Feed [7].

Metode corporate feed line digunakan secara umum dan banyak diaplikasikan dalam berbagai bidang.
Metode ini memiliki kontrol saluran di setiap patch dan sesuai pada penggunaan saluran yang meruncing kedua ujungnya atau pada transformer $1 / 4$ panjang gelombang $(\lambda)$ antena. Pada penelitian ini elemen patch dihubungkan dengan saluran pencatu dengan metode impedansi transformer $1 / 4 \lambda$ atau sering disebut teknik pembagi daya Wilkinson.

Setiap elemen yang sama dari patch antena memiliki resitansi input $R_{\text {in }}$. Elemen resistansi ini akan matched dengan impedansi saluran transmisi $\mathrm{Z}_{1}, Z_{2}$ dan arus pada masing-masing patch $\left(\mathrm{I}_{1}\right.$ dan $\left.\mathrm{I}_{2}\right)$ yang digunakan untuk pembagian daya. Hal ini dapat dilakukan dengan teknik pembagian daya Wilkinson (Gambar 3). Karakteristik impedansi $\sqrt{2} \mathrm{Z}_{0}$ dan isolasi lumped resistor $2 \mathrm{Z}_{0}$ dengan kondisi semua port bernilai sama $\mathrm{Z}_{1}=\mathrm{Z}_{2}=\mathrm{Z}_{0}[8]$.

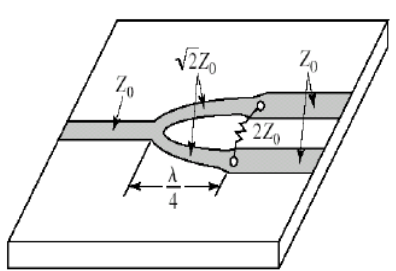

(a)

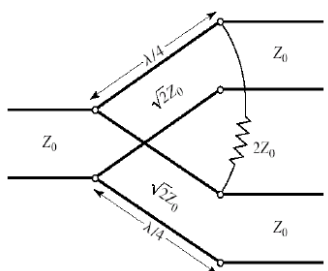

(b)
Gambar 3. (a) Pembagi Daya Wilkinson pada Microstrip Line, (b) Rangkaian Ekivalen Line Transmisi [8]

Apabila nilai impedansi pada Gambar 3. dari saluran transmisi transformator $1 / 4 \lambda$ adalah $Z$, maka besarnya impedansi saluran tersebut adalah

$$
Z=\sqrt{2} \mathrm{Z}_{0}
$$

Kemudian ditentukan nilai panjang saluran transmisi transformator yaitu

$$
l=1 / 4 \lambda_{g}
$$

dengan,

$$
\lambda_{g}=\frac{\lambda_{0}}{\sqrt{\varepsilon_{e f f}}}
$$

Sedangkan lebar saluran pencatu $\left(W_{0}\right)$ adalah

$$
\begin{aligned}
W_{0}=\frac{2 h}{\pi}\{B-1-\ln (2 B-1) & \\
& +\frac{\varepsilon_{r}-1}{\varepsilon_{r}+1}\left[\ln \left(B-1+0,39-\frac{0,61}{\varepsilon_{r}}\right]\right.
\end{aligned}
$$

dengan,

$$
\begin{gathered}
A=\frac{Z_{0}}{60}\left\{\frac{\varepsilon_{r}}{2}\right\}^{1 / 2}+\frac{\varepsilon_{r}-1}{\varepsilon_{r}+1}\left\{0,23+\frac{0,11}{\varepsilon_{r}}\right\} \\
B=\frac{60 \pi^{2}}{Z_{0} \sqrt{\varepsilon_{r}}}
\end{gathered}
$$

\section{DESAIN SISTEM}

\section{A. Desain Antena}

Antena mikrostrip yang dirancang adalah antena mikrostrip hexagonal patch array pada frekuensi 2,4 $\mathrm{GHz}$ dengan metode corporate feed line. Substrat yang digunakan adalah FR4 Epoxy dengan konstanta dielektrik $\left(\varepsilon_{\mathrm{r}}\right)$ sebesar 4,3 . Perancangan antena tersebut menggunakan software Computer Simulation Technology (CST) 2014 Microwave Studio. Antena yang dirancang memiliki dimensi $30,5 \times 38,5 \mathrm{~mm}$. 
Sebelum menentukan dimensi patch antena maka terlebih dahulu ditentukan panjang gelombang di ruang bebas $\left(\lambda_{0}\right)$ dengan perambatan ruang bebas (c) sebesar $3 \times 10^{8} \mathrm{~m} / \mathrm{s}$ pada frekuensi kerja $2,4 \mathrm{GHz}$. Sesuai Persamaan 7 [9] berikut, diperoleh nilai $\lambda_{0}$ sebesar 125 $\mathrm{mm}$.

$$
\lambda_{0}=\frac{c}{f}
$$

Kemudian dilakukan penghitungan dimensi elemen peradiasi antena yang terdiri dari panjang sisi hexagonal antena $(s)$, lebar $(W)$ dan panjang $(L)$ [9], [10]. Panjang sisi hexagonal antena dan lebar antena dapat dihitung menggunakan Persamaan 8 dan 9sebesar 19,4 mm dan $38,5 \mathrm{~mm}$

$$
\begin{aligned}
s & =\frac{c}{3.1033 f_{r} \sqrt{\varepsilon_{r}}} \\
\mathrm{~W} & =\frac{\mathrm{c}}{2 \mathrm{f}_{\mathrm{r}} \sqrt{\left(\varepsilon_{\mathrm{r}}+1\right) / 2}}
\end{aligned}
$$

Untuk menentukan panjang $(L)$ patch, maka terlebih dahulu ditentukan nilai konstanta dielektrik $\left(\varepsilon_{\text {reff }}\right)$ dan nilai panjang tambahan $\Delta L$ meggunakan Persamaan 11 dan 12 .

$$
\begin{gathered}
\varepsilon_{r e f f}=\frac{\left(\varepsilon_{r}+1\right)}{2}+\frac{\left(\varepsilon_{r}-1\right)}{2}\left[1+12 \frac{h}{W}\right]^{-1 / 2} \\
\frac{\Delta L}{h}=0,412 \frac{\left.\left(\varepsilon_{r e f f}+0,3\right)+\frac{W}{h}+0,264\right)}{\left(\varepsilon_{\text {reff }}-1,258\right)\left(\frac{W}{h}+0,8\right)} \\
L_{r e f f}=\frac{c}{2 f_{r} \sqrt{\varepsilon_{\text {reff }}}} \\
L=L_{\text {reff }}-2 \Delta L
\end{gathered}
$$

Dari hasil perhitungan Persamaan 12 dan 13 diperoleh panjang patch sebesar 30,5 mm. Hasil perhitungan dari persamaan-persamaan tersebut kemudian diaplikasikan ke dalam simulasi antena menggunakan software CST Microwave studio.

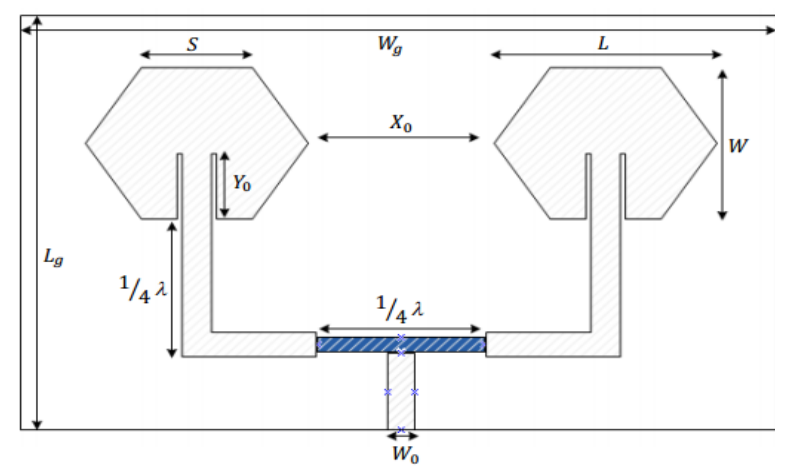

Gambar 4. Geometri Antena Hexagonal Patch Array Tampak Depan.

Geometri antena mikrostrip sesuai persamaan tersebut ditunjukkan pada Gambar 4. Patch berbentuk hexagonal yang disusun secara array. Bahan substrat dielektrik yang digunakan adalah FR4 dengan $\varepsilon_{r}$ sebesar 4,3 dengan ketebalan substrat 1,5 $\mathrm{mm}$ sedangkan material tembaga yang digunakan mempunyai ketebalan $0,1 \mathrm{~mm}$.

Hasil dari desain ukuran geometri antena hexagonal patch array ditunjukkan pada Tabel 1.
TABEL 1

UKURAN DIMENSI ANTENA HEXAGONAL PATCH ARRAY

\begin{tabular}{|c|l|c|}
\hline $\begin{array}{c}\text { Dimensi } \\
\text { Antena }\end{array}$ & \multicolumn{1}{|c|}{ Keterangan } & $\begin{array}{c}\text { Ukuran } \\
(\mathbf{m m})\end{array}$ \\
\hline $\mathrm{L}$ & Panjang patch & 30,5 \\
\hline $\mathrm{W}$ & Lebar patch & 38,5 \\
\hline $\mathrm{W}_{0}$ & Lebar saluran transmisi / feedline & 2,8 \\
\hline $\mathrm{S}$ & Panjang sisi hexagonal & 19,4 \\
\hline $\mathrm{W}_{\mathrm{g}}$ & Lebar ground plane & 47,5 \\
\hline $\mathrm{L}_{\mathrm{g}}$ & Panjang ground plane & 42 \\
\hline $\mathrm{Y}_{0}$ & Panjang saluran matching impedansi & 11,06 \\
\hline $\mathrm{X}_{0}$ & Jarak antar sisi elemen & 24 \\
\hline
\end{tabular}

Berdasarkan Tabel 1 tersebut maka dapat diimplementasikan sebuah antena hexagonal patch array seperti ditunjukkan pada Gambar 5.

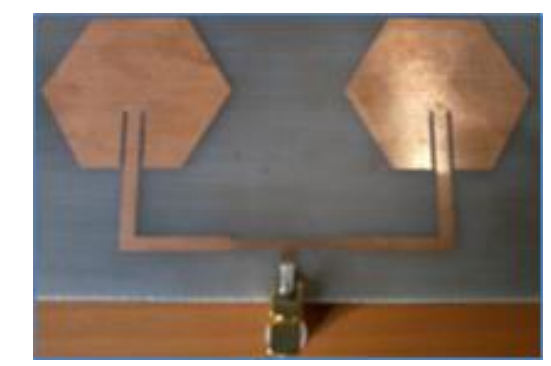

Gambar 5. Antena Mikrostrip Hexagonal Patch Array Hasil Pabrikasi.

\section{B. Desain Power Harvester}

Power Harvester berfungsi sebagai pengubah gelombang elektromagnetik menjadi arus DC [1]. Rangkaian terdiri dari kombinasi rangkaian rectifier dan voltage doubler. Rangkaian rectifier berfungsi menyearahkan tegangan AC yang dihasilkan oleh antena menjadi tegangan DC [2]. Sedangkan rangkaian voltage doubler berfungsi untuk menguatkan tegangan yang masuk dalam rangkaian. Rangkaian ini terdiri dari diode schottky HSMS-2860 [11] dan kapasitor mika 2,2 $\mathrm{pF}$. Skema rangkaian power harvester ditunjukkan seperti pada Gambar 6.

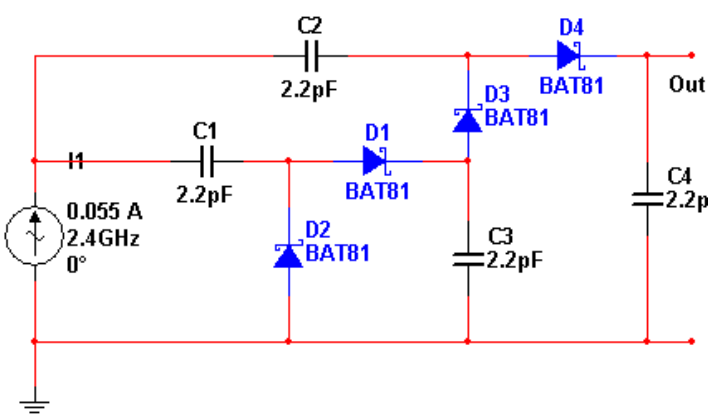

Gambar 6. Skema Rangkaian Power Harvester.

\section{Metode Penelitian}

Data awal diperoleh dari hasil pemodelan antena antara lain berupa dimensi antena, konduktansi pada patch antena dan impedansi saluran. Data tersebut kemudian disimulasikan menggunakan CST Microwave Studio 2014 sehingga diperoleh parameter antena yang meliputi VSWR, return loss, bandwidth, gain, pola radiasi, polarisasi, impedansi. Pada simulasi ini juga dapat diketahui pengaruh perubahan dimensi patch dan 
jarak antar patch pada antena. Pemodelan antena dengan pendekatan elektromagnetik dilakukan dengan metode pemodelan transmission line dan corporate feed line Kemudian data hasil simulasi tersebut digunakan untuk analisis output pada rangkaian akhir rectenna yaitu pada rangkaian pengkonversi RF menjadi DC.

Proses analisis hasil simulasi dari software CST, yaitu dengan cara merubah variabel antar elemen array kemudian diamati nilai parameter antena yang yaitu return loss, VSWS, gain. Perubahan jarak patch antar elemen antena akan berpengaruh terhadap nilai daya dan parameter lainnya.

Flow Chart metode penelitian ditunjukkan pada Gambar 7.

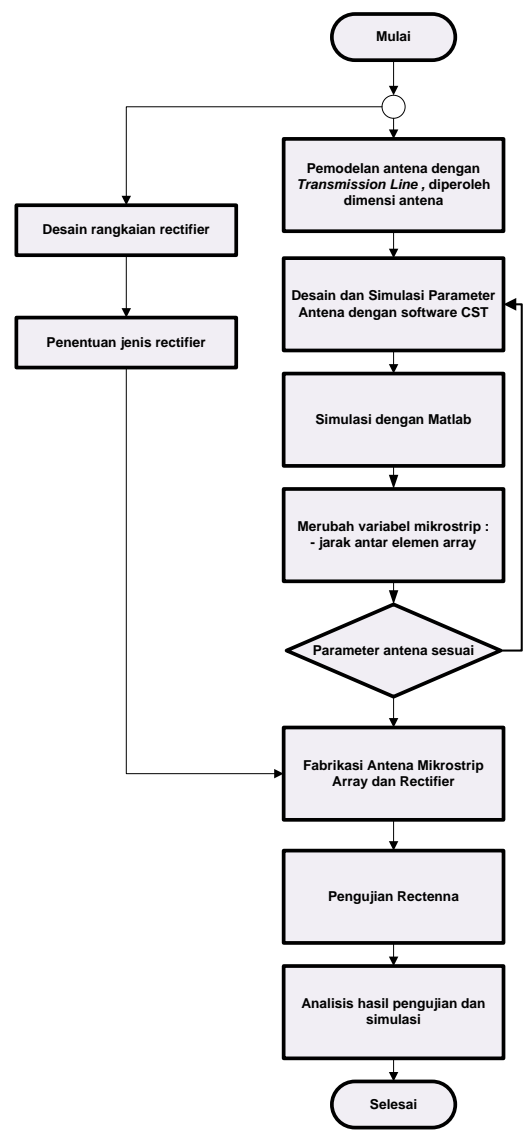

Gambar 7. Flow Chart Metode Penelitian.

\section{HASIL DAN ANALISIS}

Setelah dilakukan pengujian berupa simulasi dan pengukuran terhadap antena dan rectifier, didapatkan parameter-parameter berikut:

\section{A. Return Loss}

Hasil simulasi return loss dari antena mikrostrip hexagonal patch array ditunjukkan pada Gambar 8 .

Berdasarkan hasil simulasi tersebut, didapatkan nilai return loss pada frekuensi 2,4 GHz sebesar $-33,381$ dB. Nilai ini berada jauh di bawah $-10 \mathrm{~dB}$ yang merupakan batas nilai return loss yang artinya daya yang dipantulkan sangat sedikit dan mendekati kondisi yang match antara transmitter dan beban/antena. Frekuensi kerja yang diketahui dari hasil simulasi yaitu dari 2,355 GHz sampai dengan 2,44 GHz. Antena ini dibuat untuk aplikasi WLAN dengan lebar frekuensi sebesar 0,084 GHz.

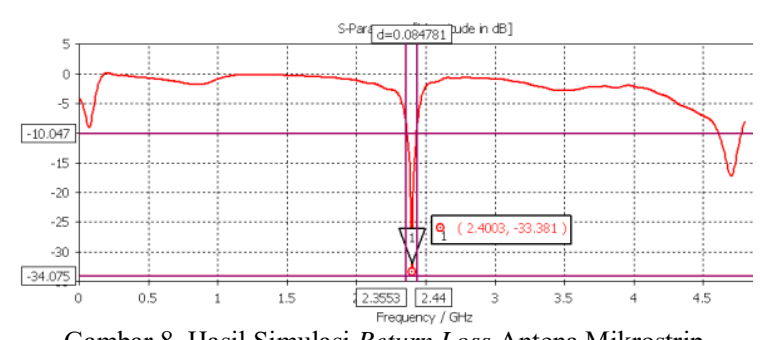

Gambar 8. Hasil Simulasi Return Loss Antena Mikrostrip Hexagonal Patch Array pada Frekuensi 2,4 GHz.

Selain dari hasil simulasi, return loss juga diperoleh dari hasil pengukuran menggunakan Vector Network Analyzer tipe N9923A seperti Gambar 9.

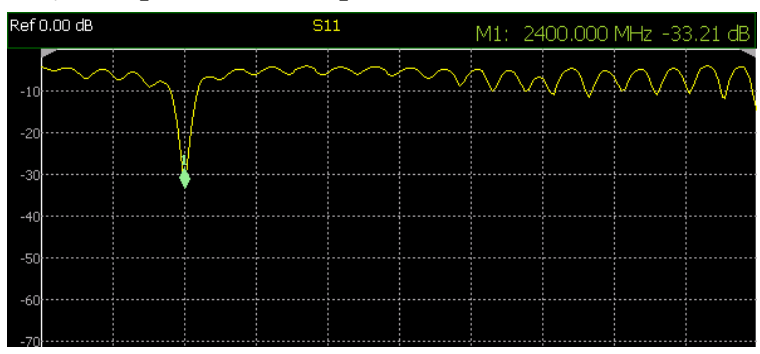

Gambar 9. Hasil pengukuran return loss dengan Vector network analyzer N9923A pada frekuensi 2,4 GHz

Gambar 9 menunjukkan bahwa return loss yang dihasilkan dari antena yang telah dipabrikasi pada frekuensi 2,4 GHz memiliki nilai return loss sebesar $-33,21 \mathrm{~dB}$. Antena hasil pengukuran memiliki range frekuensi kerja dari 2,355 $\mathrm{GHz}$ sampai dengan 2,55 GHz sehingga bandwidth-nya sebesar $0,145 \mathrm{GHz}$.

\section{B. Bandwidth}

Bandwidth antena adalah range frekuensi antena dengan beberapa karakteristik, sesuai dengan standar yang telah ditentukan. Dari penelitian yang telah dilakukan, bandwidth antena dapat diketahui dari frekuensi kerja antena baik dari hasil simulasi maupun dari hasil pengukuran seperti pada Tabel 2 .

TABEL 2

BANDWIDTH ANTENA MIKROSTRIP HEXAGONAL PATCH ARRAY

\begin{tabular}{|c|c|c|}
\hline Hasil & $\begin{array}{c}\text { Frekuensi Resonansi } \\
(\mathbf{G H z})\end{array}$ & $\begin{array}{c}\text { Bandwidth } \\
(\mathbf{G H z})\end{array}$ \\
\hline Simulasi & $2,36-2,446$ & 0,084 \\
\hline Pengukuran & $2,355-2,50$ & 0,145 \\
\hline
\end{tabular}

\section{VSWR}

Salah satu parameter penting berikutnya dalam suatu antena adalah Voltage Standing Wave Ratio (VSWR). VSWR adalah pengukuran dasar dari impedansi matching antara saluran transmisi dan antena. Hasil simulasi VSWR ditunjukkan seperti Gambar 10.

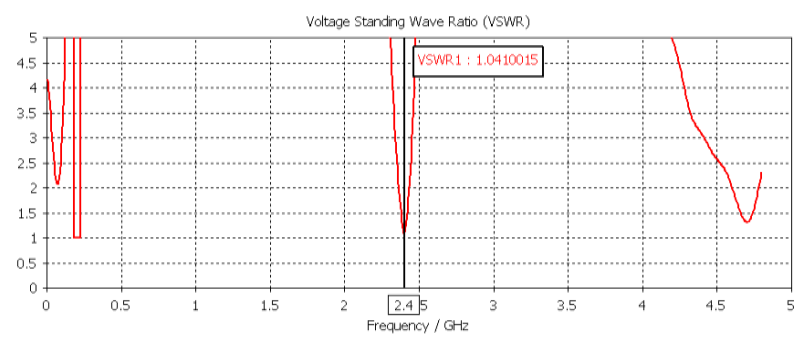

Gambar 10. Hasil Simulasi VSWR Mikrostrip Hexagonal Patch Array pada Frekuensi 2,4 GHz. 
Selain dari hasil simulasi, VSWR antena mikrostrip hexagonal patch array juga diukur dengan menggunakan Agilent Vector Network Analyzer seperti terlihat dalam Gambar 11.

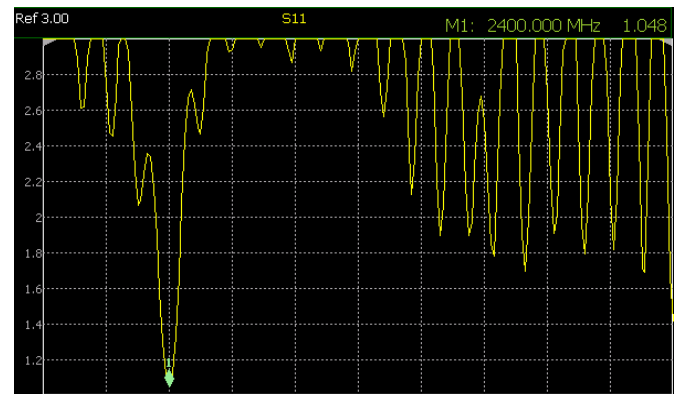

Gambar 11. Hasil Pengukuran VSWR Dengan Agilent Vector Network Analyzer N9923A.

Berdasarkan hasil simulasi dan pengukuran, hasil VSWR yang didapatkan pada frekuensi $2,4 \mathrm{GHz}$ adalah 1,041 dan 1,048. Data hasil simulasi dan pengukuran memiliki selisih yang kecil dan memenuhi persyaratan nilai VSWR yaitu lebih kecil dari dua (VSWR $<2$ ). Hal ini membuktikan antena mikrostrip yang telah dibuat memenuhi syarat karakteristik antena yang baik karena hampir tidak ada gelombang pantul dengan nilai koefisien refleksi yang sangat kecil.

\section{Gain dan Pola Radiasi}

Pengukuran gain antena dapat dilakukan dengan cara membandingkan antara gain antena mikrostrip hexagonal array dengan gain antena referensi. Antena referensi yang digunakan adalah antena USB adapter wifi TL-WN722N. USB adapter wifi digunakan sebagai penerimaan sinyal dari access point, dan memiliki gain sebesar $4 \mathrm{dBi}$. Adapun perhitungan gain yang diukur dapat dicari sesuai Persamaan 12.

$$
G_{u}=G_{\text {reff }}+P_{u}-P_{\text {reff }} \mathrm{Z}_{0}
$$

Hasil level daya penerimaan dari antena USB adapter wifi TL-WN722N frekuensi $2,4 \mathrm{GHz}$ adalah -38 $\mathrm{dBm}$, sedangkan maksimum level daya penerimaan dari antena mikrostrip hexagonal patch array adalah -37 $\mathrm{dBm}$ sehingga diperoleh nilai gain yang diukur sebesar $5 \mathrm{dBi}$. Sedangkan gain dari hasil simulasi dapat diperoleh dari grafik polar yang dapat dilihat dari magnitude mainlobe yang dihasilkan oleh pola radiasi antena mikrostrip hexagonal patch array seperti pada Gambar 12.

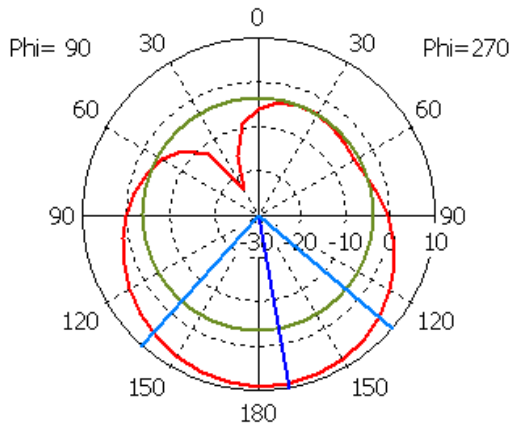

Gambar 12. Pola Radiasi Antena Mikrostrip Hexagonal Patch Array.

Gambar 12 menunjukkan gain yang diperoleh dari hasil simulasi sebesar $8,73 \mathrm{dBi}$ sedangkan nilai Half
Power Beam Width (HPBW) yang diperoleh adalah 91,4 $4^{\circ}$. HPBW adalah lebar sudut yang memisahkan dua titik setengah daya pada pancaran utama dari pola radiasi. Titik penurunan setengah daya terletak pada 3 $\mathrm{dB}$. Nilai side lobe level (lobe kecil yang ada di dekat main lobe) pada pola radiasi antena adalah $-12,4 \mathrm{~dB}$.

\section{E. Level Daya}

Daya terima dari suatu antena berkaitan dengan kemampuan antena tersebut dalam menangkap sinyal di udara bebas sehingga dapat diubah menjadi tegangan listrik setelah diproses di rangkaian rectifier. Pengukuran level daya menggunakan Spectrum Analyzer dengan nilai daya sebesar $-33,34 \mathrm{dBm}$. Sedangkan jika dilihat dari hasil simulasi dengan menggunakan CST maka diperoleh nilai level daya sebesar 0,499 W.

Setelah diketahui nilai dari daya yang diterima antena maka daya tersebut sebagai daya input ke rangkaian rectifier. Nilai daya ini berpengaruh terhadap nilai tegangan output rectifier. Setelah dilakukan simulasi terhadap rangkaian rectifier maka dihasilkan tegangan maksimal sebesar $1,541 \mathrm{~V}$.

Perubahan jarak antar elemen array memiliki pengaruh yang besar terhadap daya yang diterima antena mikrostrip. Apabila jarak antar elemen terlalu dekat atau saling berhimpit maka akan terjadi electromagnetically coupling dan apabila jarak antar elemen terlalu jauh maka akan memperbesar nilai rugirugi daya. Adanya pengaruh jarak terhadap daya terima ditunjukkan seperti pada Gambar 13.

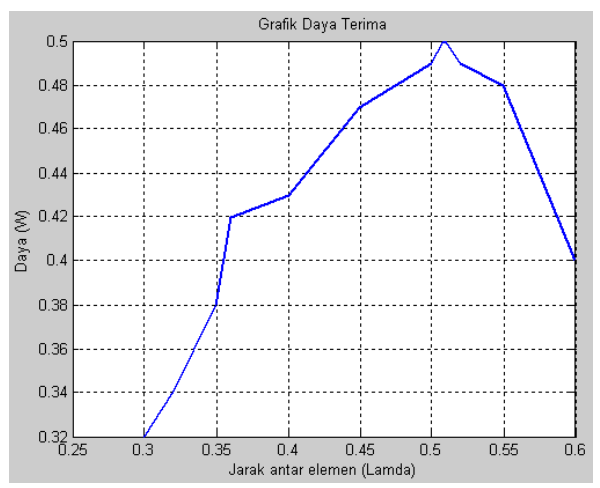

Gambar 13. Pengaruh Jarak Antar Elemen Array Terhadap Daya Terima.

\section{KESIMPULAN}

Dalam penelitian ini, telah dilakukan desain antena hexagonal patch array menggunakan metode Corporate Feed Line dan rangkaian power harvester. Pemodelan antena untuk mendapatkan data dimensi antena telah dilakukan, kemudian dilakukan pengujian parameter antena melalui prosedur pengukuran dan analisisnya berdasarkan perubahan variabel yaitu jarak antar elemen patch array antena yang berpengaruh terhadap daya terima antena. Berdasarkan semua hasil dan pembahasan yang telah dijelaskan pada bagian sebelumnya, maka dapat disimpulkan sebagai berikut:

1. Hasil pengukuran Rectenna dengan antena hexagonal patch array menghasilkan nilai return loss sebesar -33,381 dB pada frekuensi tengah 2,4 $\mathrm{GHz}$ serta bandwidth antena adalah $0,145 \mathrm{GHz}$ 
yang mengalami peningkatan dari hasil simulasi (0,084 GHz).

2. VSWR yang diperoleh dari hasil simulasi adalah 1,041 dan pengukuran adalah 1,048. Hal ini membuktikan antena mikrostrip yang telah dibuat memenuhi syarat karakteristik antena yang baik karena nilai VSWR $<2$, dan mendekati 1 sehingga mendekati kondisi match terhadap saluran transmisinya .

3. Gain yang dihasilkan dari hasil pengujian cukup besar yaitu $5 \mathrm{dBi}$ dengan pola radiasi omnidirectional, sedangkan pada hasil simulasi direktivitas pada main lobe terbesar memiliki gain sebesar 8,73 dBi.

4. Daya optimum sebesar 0,499 W berdasar hasil simulasi pada antena hexagonal patch array ini terletak pada jarak 63,5 mm antar elemen patch.

5. Berdasarkan simulasi dihasilkan tegangan output rangkaian power harvester sebesar $1,541 \mathrm{~V}$.

\section{UCAPAN TERIMA KASIH}

Penulis mengucapkan terima kasih kepada dosen pembimbing yaitu Bapak Sholeh Hadi Pramono dan Ibu Erni Yudaningtyas yang telah membantu dan membimbing penulis dalam menyelesaikan penelitian tesis ini. Penulis juga mengucapkan terima kasih kepada Kemenristek Dikti yang telah memberikan beasiswa studi kepada penulis.

\section{Daftar Pustaka}

[1] O. Imatsu, E. Setijadi, dan Wirawan, "Rancang bangun antena mikrostrip pada frekuensi GPS L1 berbasis sistem transfer daya nirkabel", Jurnal Teknik POMITS, vol. 1, no. 1, hal. 1-6, 2012.

[2] Anuroop, D. Gangwar, and R. L. Yadava, "Design and analysis of a pentagonal rectenna", in Proceedings of International Conference on Signal Processing and Integrated Networks (SPINZ), 2014, pp. 654 - 658.

[3] O. Olgun, C. C. Chen, and J. L. Volakis, "Investigation of rectenna array configurations for enhanced rf power harvesting", IEEE Antennas And Wireless Propagation Letters, vol. 10, April 2011, pp. $262-265$.

[4] N. Zhu, K. Chang, M. Tuo, P. Jin, H. Xin, and R. W. Ziolkowski, "Design of high-efficiency rectenna for $1,575 \mathrm{ghz}$ wireless low power transmission", in Proceedings of 2011 IEEE Radio and Wireless Week (RWW 2011) - 2011 IEEE Radio and Wireless Symposium (RWS 2011), Jan 2011, pp. 90-93.

[5] M. T. I. Huque, M. A. Chouwdury, M. K. Hosain, and M. S. Alam, Performance analysis of corporate feed rect angular element and circular patch elemen $4 \times 2$ mikcrostrip array antenna”, International Journal of Advanced Computer Science and Application (IJACSA), vol. 2. no. 8, pp. 74-79, 2011.

[6] S. Bin Alam, M. A. Ullah, and S. Moury, "Design of a low power $2.45 \mathrm{GHz}$ RF energy harvesting circuit for rectenna harvesting circuit for rectenna, in Proceedings of 2013 International Conference on Informatics, Electronics \& Vision (ICIEV), May 2013, pp. 1-4.

[7] R. Brancroft, Microstrip and Printed Antenna Design, 2nd ed., Raleigh, NC-USA: Scitech Publishing, Inc, 2009.

[8] D. M. Pozar, Microwave Engineering, 4th ed., New York, USA: John Wiley \& Sons, Inc, 2011.

[9] C. A. Balanis, Antena Theory: Analysis Design, 3rd ed. New Jersey, USA: John Wiley \& Sons, Inc, 2005.

[10] S. Basu, A. Srivastava, and A. Goswami, "Dual frequency hexagonal microstrip patch antenna", Int. J. Sci. Res. Publ., vol 3 , iss.11, pp. 1-9, November 2013.

[11] "HSMS-286x series surface mount microwave schottky detector diodes", Avago Technologies, United States, 2009. 